\title{
Editorial
}

\section{Delivering Alpha conference}

Journal of Asset Management (2014) 15, 219-221. doi:10.1057/jam.2014.26

The fourth annual Delivering Alpha conference took place at the Pierre Hotel in NYC on 16 July 2014. The top hedge fund titans and top global investors gathered to discuss stock picks, the economy and finding opportunities in today's global markets. First on the agenda was the US Secretary of the Treasury Jacob J. Lew, who urged US financial firms to beef up their cyber security systems to avoid future threats that could disrupt the US economy, and the stability of the financial system. He also suggested new laws against cybercrime and for US corporations to demonstrate "economic patriotism' while penalizing US firms for rerouting their corporate headquarters overseas to pay fewer taxes while keeping their main operations in the United States. Lew suggested that corporations stop these inversions.

Ken Griffin, Founder and CEO of Citadel, who owns stock of 21st Century Fox and Time Warner, believes the merger between these companies will take place even though Time Warner rejected the US $\$ 80$ billion offer. He also highlighted that the merger would be good for investors and that in the end Rupert Murdoch will succeed.

The next panel on the global stage consisted of four well-known managers. Lee Ainslie, CEO of Maverick Capital, has been a well-known hedge fund manager since 1993. Janet Erdoes, CEO of J.P. Morgan Asset Management, suggested that many retail investors do not understand the impact of duration and convexity when investing in bonds, but believes the market is robust. Paul Marshall, CIO and Chairman of Marshall Wace, and Jane Mendillo, President and
CEO of the Harvard Management

Company, also concurred with the others that stocks, bonds and credit markets are overvalued.

Leon Cooperman, Chairman of Omega Advisors and a well-known hedge fund manager, once again gave his 10 best stock picks in his fourth appearance at the conference since it started. Over the last 2 years his stock picks presented at the conference have yielded a hit rate in the 90 per cent range; however, he suggested that his record may be blemished this year because of the high level of current markets and suggested that 'there are pockets of overvaluation'. He also highlighted that the 'market is not exuberantly bullish' and the 'market is in a zone of okay'. Furthermore, he added that the Fed will likely hike rates in 2015, which would be 'constructive for the markets', and highlighted that the last time the Fed increased rates was in 2006 . He also added that merger deals are getting larger, which bodes well for markets. His best ideas for 2014 are ACT, C, JPM, GLPI, NAO, QEP, SVU, 577-HKG, MONI.LN, TMO, KKR and SD.

Larry Robbins, CEO and Portfolio Manager from Glenview Capital, gave seven of his best stock picks: TMO, MON, HCA, HTZ, NOV, CRI and FLEX. In addition, he was for 'reform' or 'regime change' in markets that have been ignored. Michael Novogratz, Principal and Director of Fortress Investment Group, considered that emerging markets such as India, Argentina, Brazil and Japan may experience some further growth.

Stanley Druckenmiller, ex-Soros Chief and Founder of Duquesne Capital 
Management, believes the Fed policy is 'puzzling and baffling'. In addition, he suggested that the Fed fuelled the housing bubble of the mid-2000s and stressed that the current 'Fed policy makes no sense from a risk-return perspective'. In addition, he strongly argued that the Fed is 'clueless' in staying its course on 'aggressive market intervention'. He also mentioned 'that the IPO market is looking similar to 1999 dot com bubble and according to him there could be a setback after the ending of QE'. Lastly, he strongly advocated that IBM's 'growth has been due to its buyback of its stock by borrowing money, while tripling its debt it tripled their buyback', which is what many firms in the United States are doing and the reason why productivity is down. The buyback has been camouflaged as growth. He said that 'spurring growth with 0 per cent rates is not the answer'. In fact, over the last 6 years there has been no growth in IBM sales.

Jim Breyer, Founder and CEO of Breyer Capital and Partner at Accel Partners, suggested that 'Google will likely become the first company with a trillion dollar marker cap', with both Facebook and Google gobbling up more firms down the line. $\mathrm{He}$ also mentioned that he is bullish on digital currencies over the next 5-7 years. Shana Fisher, Managing Partner at High Line Venture Partners, argued that corporations engaged in 'producing videos' will do well in the future.

John Paulson, Founder and Managing Partner at Paulson \& Co. Inc., showed a great deal of interest in the oil sector, 'particularly on extraction technology', and reiterated from last year's Delivering Alpha conference that buying a home is still the 'best investment' because of the low lock-up rates over 30 years.

Josh Birnbaum, CIO of Tilden Park Capital, stated that a great deal of 'mortgage putbacks are highly discounted' and described how Bank of America purchased countrywide ‘bad mortgages'. Deepak Gulati,
CIO of Argentière Capital, is bullish on Asian indexes such as China, Japan and Korea, and positive on the US energy market and European financial stocks. Jeffrey Smith, CEO and CIO of Starboard Value, sees that MWV is undervalued, and with the stock price going from $\$ 44$ to $\$ 51$ his firm has the largest stake with 5.6 per cent of the float. MWV's chemical portion of the business could likely 'sell-off as a spinoff for more than $\$ 3$ billion'.

Ken Moelis, Chairman and CEO of Moelis \& Company, who acted as an adviser to Herbalife, considers that the 'attacks' of activist hedge fund manager Bill Ackman on Herbalife are 'destroying the firm's value'. Nelson Peltz, Founding Partner and CEO at Trian Fund Management, discussed last year's deal with Pepsi, which holds a position of 12.4 million shares bought for around $\$ 60$ and now worth $\$ 90$ a share. He stressed that Pepsi's stock has increased not because of earnings but rather because of his presence as an activist investor. $\mathrm{He}$ is attempting to remove bad management and also Pepsi's dysfunctional board, which may wind up in a proxy fight. In addition, he maintains that he has $6-10$ positions in his portfolio with 6.6 million shares in Lazard Ltd. Peltz anticipates that talks with DuPont to augment shareholder wealth will likely be productive since he owns 6.14 million shares.

Carl Icahn, activist hedge fund manager running his $\$ 32$ billion fund, restated what he said at last year's conference, that many CEOs are doing a bad job and many corporations have the wrong CEOs at the helm. Icahn was questioned by Scott Wapner as to whether as an 'activist he is in it for the short-term' to make a quick buck, to which Icahn replied that he has held stocks for between 7 and 20 years and has created billions in value for investors. He also briefly mentioned that Tim Cook, CEO of Apple, is doing a great job, with new products likely to come out. Carl Icahn's firm IEF has made money because of dysfunctional boards and bad management, 
with many investors backing him up over the years. He also criticized Warren Buffet for abstaining from voting for Coca-Cola. As for Family Dollar, he declared that it was in a 'good area with poor management' and that the CEO should be replaced with a good CEO who can run the firm on his own without the interference of the board. He is also worried about the Fed's 'excessive printing of money'. He noted that activist hedge funds averaged 22 per cent from 2000 to 2014 and 36 per cent over 2009-2013, while the hedge fund index returned a meagre 4 per cent during the former period. Finally, Icahn stated that many pension funds are poorly run and in this bull market their returns are only 4 per cent and many will likely go bankrupt.

The mystery guest was Bill Ackman from Pershing Square Capital Management LP, and he shared the stage with Icahn. Ackman spoke about how Icahn was correct in saying that activists 'are the voice of the shareholders', with many investors supporting Icahn over the years. Ackman believes the Paulson deal between Allergan and Valeant will happen. The Allergan board refused to meet Valeant, claiming Valeant was largely an accounting fraud.

For the fourth year in a row the Delivering Alpha conference, considered by many as the top hedge fund conference, 'delivered' with its star roster of hedge fund managers, politicians and money managers. Hundreds of institutional investors, pension fund managers, retail investors, endowment fund members, insurance companies, family offices, accountants and lawyers migrated to the conference, again packing the room to capacity. The conference was a tremendous success and no doubt will continue to amaze in July 2015.

Greg N. Gregoriou

Professor of Finance SUNY (Plattsburgh)

Derivatives Editor

E-mail: gregorg@plattsburgh.edu 